\author{
${ }^{1}$ UTP University of Science and Technology, Faculty of Agriculture and Biotechnology \\ Department of Soil Science Protection, Bernardyńska Str. 6, 85-029 Bydgoszcz, Poland \\ ${ }^{2}$ UTP University of Science and Technology, Faculty of Agriculture and Biotechnology, Sub-Department of Biochemistry \\ Bernardyńska Str. 6, 85-029 Bydgoszcz, Poland
}

\title{
Effect of forest fire on changes in the content of total and available forms of selected heavy metals and catalase activity in soil
}

\begin{abstract}
The aim of the paper was to assess the effect of forest fire on the content of total and available forms of zinc, copper, lead, nickel and cadmium, as well as the activity of catalase in soil. The study was performed directly (2012) and a year after the fire (2013). The fire had a significant effect on the content of those heavy metals in surface horizons, however, it did not result in their rapid growth. The concentrations of total forms of metals did not exceed the norms provided for in Regulation of the Polish Minister of the Environment. The soil samples analysed can be considered unpolluted with those metals. The availability coefficients calculated showed an unfavourable higher availability of lead and cadmium over zinc and copper. The statistical analysis showed a significant effect of fire on the activity of catalase. Resistance of soil $(R S)$ for catalase demonstrated lower values in the year 2012 as compared with 2013 (except for B soil). The calculated values of time index $(T I)$ pointed to the activation of the enzyme a year after the fire. The Ward clustering method facilitated determining similarities between the sites in two research years (2012 and 2013) with the selected soil parameters. With the PCA method a negative effect of fire was identified.
\end{abstract}

Keywords: catalase, fire forest, heavy metals, resistance of soil

\section{INTRODUCTION}

Forest fire is a disaster phenomenon with a destructive effect on the functioning of forest ecosystems. It causes death to many plant and animal species as well as affects soil properties. During fire soil is exposed to varied thermal conditions and the depth of changes caused by fire is determined by three major factors: types of fire (at the ground - lower or at the top-upper), its duration and intensity (Iglesias et al. 1997). Immediately after fire a short-term increase in soil fertility can occur, however, after some time, nutrients, released by the effect of fire, get leached from it and this is how fire makes its fertility exhausted (Brais et al. 2000). A destructive impact of fire results in a decrease in the number and diversity of soil microand macrofauna and in weakening the enzymatic activity of soils (Prędecka et al. 2010). Fire also affects physical and chemical soil properties; a decrease in structure, porosity, organic matter content, $\mathrm{pH}$ increase (Iglesias et al. 1997, Januszek et al. 2001, Carter and Foster 2004, Certini 2005, Ekinci 2006, Gonet et al. 2009, Miesel et al. 2012). The changes can lead to a number of disturbances in the ecosystems flora and fauna dynamics development (DeBano 2000, Clark 2001, Bogacz et al. 2013). During fire temperature deep down the soil increases. If temperature on the surface is about $438^{\circ} \mathrm{C}$, then $3 \mathrm{~cm}$ deep temperature is $25.6^{\circ} \mathrm{C}$, and $7 \mathrm{~cm}$ deep $-17^{\circ} \mathrm{C}$; such a rapid change in temperature can destroy microorganisms, a source of enzymes. One of the key enzymes defending organisms from negative effects of oxidative stress is catalase. In soil environment catalase is present in microorganisms cells using oxygen for respiration processes (Brzezińska 2006). According to Wang et al. (2012), the activity of catalase plays an important role in soil solution chemistry and can change oxidation-reduction reaction of soil. There are many reports on the effect of fires mostly on biological soil properties (Hamman et al. 2008, Olszowska 2009, Lemanowicz and Bartkowiak 2015), however, few papers cover the content of microelements.

The aim of the paper has been to evaluate the effect of forest fire on the contents of total and available forms of zinc, copper, lead nickel and cadmium as well as the activity of catalase in soil immediately and a year after the fire. 


\section{MATERIAL AND METHODS}

The research area covered the site after fire found in the Fordon forest $\left(53^{\circ} 07^{\prime} \mathrm{N}, 18^{\circ} 06^{\prime} \mathrm{E}\right)$ in Bydgoszcz. The Fordon forest is a pine forest, the composition of which is dominated by Scots pine (Pinus sylvestris), on sandy and sandy-loamy soils.

The site after fire occurred in March 2012 and it covered the area of about 10 ha. Fire lasted about 6 hours. Soil was sampled right after fire in the spring of 2012 and a year after fire (May 2013). After the organic layers removal soil samples was from 2 mineral horizons: $0-15 \mathrm{~cm}$ (surface horizon) and $15-30 \mathrm{~cm}$ (subsurface horizon). Four sampling locations were defined: stand not caught by fire - control area (C), border area (E ecotone) and soils caught by fire, $150 \mathrm{~m}$ (point A) and $200 \mathrm{~m}$ (point B) away from the border area. The control area was defined in pine tree stands neighbouring with the site after fire.

The soil sampling locations were determined with the scattered points method, made up of a few individual samplings from 27 points (PN-ISO 10381-2:2007P).

In the air-dried soil samples with disturbed structure, sieved through $\varnothing 2 \mathrm{~mm}$, some physiochemical properties: percent of clay fraction; total organic carbon (TOC); $\mathrm{pH}$ were presented in earlier research (Lemanowicz and Bartkowiak 2015). The total content of selected heavy metals was assayed with Crock and Severson's (1980) method and its available forms were extracted with $1 \mathrm{M} \mathrm{HCl}$ - Rinkis method. The total contents and available forms were determined applying the method of atomic absorption spectroscopy with the PU 9100X spectrometer (Philips).

The activity of catalase [E.C. 1.11.1.6] (CAT) in soil was determined with the Johnson and Temple method (1964) with $0.3 \%$ hydrogen peroxide solution as a substrate. The residual $\mathrm{H}_{2} \mathrm{O}_{2}$ was determined by titration with $0.02 \mathrm{M} \mathrm{KMnO}_{4}$ under acidic conditions.

The results facilitated a calculation of the availability factor $(A F)$ as suggested by Obrador et al. (2007), expressed as follows:

$$
A F=\left(\frac{\text { Available content }}{\text { Total content }}\right) \times 100
$$

where $A F$ - availability factor (\%).

To assay the percentage changes in the activity of catalase, as compared with the control soil, the coefficient of relative change $(R C h)$ was calculated compliant with the formula provided by Chaer et al. (2009):

$$
R C h=\left(\frac{T}{C}-1\right) \times 100
$$

where: $T$ - mean activity of catalase in the treated soil sample, $C$ - mean value obtained for the control.
Resistance of soil $(R S)$ determined according to the activity of catalase in soil was calculated using the formula proposed by Orwin and Wardle (2004):

$$
R S=1-\left[\frac{2\left|D_{0}\right|}{C_{0}+\mid D_{0}}\right]
$$

where: $D_{0}=C_{0}-P_{0}, C_{0}$ - parameter value in control soil over time $\mathrm{t}_{0}, P_{0}$ - parameter value in disturbed (burnt) soil over time $t_{0}$. The value of the resistance and resilience index is bounded by -1 and +1 .

Based on the results, the time index was calculated:

$$
\frac{\mathrm{t} 2}{\mathrm{t} 1}
$$

where $\mathrm{t} 1$ - content of the element in 2012; $\mathrm{t} 2$ - content of the element in 2013. $T I>1$ means an increase, $T I<1$ means a decrease in content of some heavy metals and activity of catalase (Lemanowicz and Krzyżaniak 2015).

Two-way analysis of variance (ANOVA) was used to determine the effects of samples of burnt soil and soil depth. The study was carried out in a randomized design.

Pearson linear correlation coefficients analysis was used to estimate the relationships between the content of total and available heavy metals, TOC, $\mathrm{pH}_{\mathrm{KCl}}$, clay, the activity of the catalase.

Principal component analysis (PCA) was applied using data for soil catalase activities, content TOC and heavy metals and soil physiochemical properties. The first two principal components (PC1 and PC2) were selected for a further interpretation of the results. Hierarchical cluster analysis (CA) with Ward's method (1963) was used to identify the similarity groups between sampling.

All analytical measurements were performed with three replications. Arithmetic mean values are shown in tables. Differences among mean values of content of the selected chemical and biochemical properties were analyzed using a factorialdesign analysis of variance (ANOVA). In these analyses, the least significant difference (LSD) was calculated using the Student's t-test at 0.05 probability. The SD value is given only in comparison in individual years.

\section{RESULTS AND DISCUSSION}

Table 1 presents the results of selected physiochemical properties. In the soils covered by fire an inconsiderable increase in $\mathrm{pH}$ value, a decrease in the content of clay fraction and an increase in organic carbon were identified (Lemanowicz and Bartkowiak 2015). Literature reports on a high forest fire intensity resulting in an increase in the soil $\mathrm{pH}$ value in surface horizons, accompanied by a decrease in the content 
TABLE 1 . The content of clay fraction, $\mathrm{pH}$ and total organic carbon (TOC) in soils

\begin{tabular}{|c|c|c|c|c|c|c|c|}
\hline \multirow[t]{2}{*}{ Objects* } & \multirow{2}{*}{$\begin{array}{l}\text { Depth } \\
\text { (cm) }\end{array}$} & \multicolumn{2}{|c|}{ Clay (\%) } & \multicolumn{2}{|c|}{$\mathrm{pH}_{\mathrm{KCl}}$} & \multicolumn{2}{|c|}{ TOC $\left(\mathrm{g} \cdot \mathrm{kg}^{-1}\right)$} \\
\hline & & 2012 & 2013 & 2012 & 2013 & 2012 & 2013 \\
\hline \multirow[t]{2}{*}{$\mathrm{C}$} & $0-15$ & 1.02 & 0.94 & 4.01 & 3.86 & 9.23 & 17.29 \\
\hline & $15-30$ & 1.08 & 0.77 & 4.22 & 4.30 & 3.90 & 4.42 \\
\hline \multirow[t]{2}{*}{$\mathrm{E}$} & $0-15$ & 0.50 & 1.25 & 4.78 & 4.56 & 16.77 & 23.11 \\
\hline & $15-30$ & 1.06 & 0.75 & 4.37 & 4.52 & 4.55 & 11.44 \\
\hline \multirow[t]{2}{*}{ A } & $0-15$ & 1.03 & 0.72 & 4.96 & 5.25 & 13.39 & 16.89 \\
\hline & $15-30$ & 1.29 & 0.14 & 4.54 & 4.75 & 5.72 & 7.15 \\
\hline \multirow[t]{2}{*}{ B } & $0-15$ & 0.83 & 0.54 & 4.99 & 4.38 & 12.22 & 14.56 \\
\hline & $15-30$ & 1.53 & 0.52 & 4.68 & 4.36 & 7.54 & 3.25 \\
\hline$S D$ & & 0.30 & 0.31 & 0.35 & 0.40 & 4.61 & 6.96 \\
\hline
\end{tabular}

${ }^{*} \mathrm{C}$ - control, $\mathrm{E}$ - ecoton, A - burned forest $150 \mathrm{~m}$ away from ecatone, $\mathrm{B}$ - burnt forest $200 \mathrm{~m}$ away from ecatone. of organic carbon and nitrogen (Schafer and Mack 2010, Aref et al. 2011, Verma and Jayakumar 2012).

The analysis of variance has shown that the content of total and available forms of heavy metals was significantly modified both by the site and the soil sampling depth (Tables 2 and 3). There was found the definitely highest content of total forms of zinc $\left(38.78 \mathrm{mg} \cdot \mathrm{kg}^{-1}\right)$, copper $\left(13.80 \mathrm{mg} \cdot \mathrm{kg}^{-1}\right)$, lead $(47.38$ $\left.\mathrm{mg} \cdot \mathrm{kg}^{-1}\right)$, nickel $\left(64.53 \mathrm{mg} \cdot \mathrm{kg}^{-1}\right)$ and cadmium (3.08 $\left.\mathrm{mg} \mathrm{kg}^{-1}\right)$ as well as available forms $\left(14.09 \mathrm{mg} \mathrm{kg}^{-1}\right.$ $\mathrm{Zn}, 3.15 \mathrm{mg} \cdot \mathrm{kg}^{-1} \mathrm{Cu}, 16.43 \mathrm{mg} \cdot \mathrm{kg}^{-1} \mathrm{~Pb}$ and 11.57 $\mathrm{mg} \cdot \mathrm{kg}^{-1} \mathrm{Ni}$ ) in surface horizons of the sites. The highest values for total forms $\mathrm{Zn}, \mathrm{Cu}$ and $\mathrm{Pb}$ were noted in the surface horisons at stand B in year 2012 while for $\mathrm{Ni}$ in stand A only in year 2013. The highest values

TABLE 2. Total content of heavy metals $\left(\mathrm{mg} \cdot \mathrm{kg}^{-1}\right)$

\begin{tabular}{|c|c|c|c|c|c|c|c|c|c|c|c|}
\hline \multirow{2}{*}{$\begin{array}{l}\text { Objects } \\
\text { I factor }\end{array}$} & \multirow{2}{*}{$\begin{array}{l}\text { Depth } \\
(\mathrm{cm}) \\
\text { II factor }\end{array}$} & \multicolumn{2}{|l|}{$\mathrm{Zn}$} & \multicolumn{2}{|l|}{$\mathrm{Cu}$} & \multicolumn{2}{|l|}{$\mathrm{Pb}$} & \multicolumn{2}{|l|}{$\mathrm{Ni}$} & \multicolumn{2}{|l|}{$\mathrm{Cd}$} \\
\hline & & 2012 & 2013 & 2012 & 2013 & 2012 & 2013 & 2012 & 2013 & 2012 & 2013 \\
\hline \multirow[t]{2}{*}{$\mathrm{C}$} & $0-15$ & 12.75 & 12.40 & 6.25 & 5.73 & 16.85 & 19.85 & 13.75 & 12.98 & 2.78 & 1.63 \\
\hline & $15-30$ & 11.60 & 10.53 & 6.63 & 5.50 & 14.00 & 15.28 & 11.50 & 12.05 & 2.78 & 1.30 \\
\hline \multirow[t]{2}{*}{$\mathrm{E}$} & $0-15$ & 26.25 & 16.38 & 8.85 & 7.25 & 21.15 & 16.58 & 13.90 & 15.48 & 3.08 & 1.68 \\
\hline & $15-30$ & 12.75 & 12.43 & 6.43 & 5.95 & 12.85 & 13.85 & 11.90 & 12.43 & 2.78 & 1.40 \\
\hline \multirow[t]{2}{*}{ A } & $0-15$ & 21.38 & 26.43 & 8.28 & 6.63 & 19.58 & 35.69 & 13.50 & 64.53 & 0.94 & 1.90 \\
\hline & 15-30 & 15.20 & 12.93 & 5.95 & 5.95 & 12.28 & 14.73 & 11.65 & 22.35 & 0.93 & 1.73 \\
\hline \multirow[t]{2}{*}{ B } & $0-15$ & 18.40 & 38.78 & 7.40 & 13.80 & 17.00 & 47.38 & 13.23 & 35.8 & 1.29 & 2.08 \\
\hline & $15-30$ & 11.43 & 11.85 & 6.75 & 4.75 & 17.00 & 14.43 & 12.05 & 7.68 & 1.07 & 1.98 \\
\hline Mean & & 16.22 & 17.10 & 7.06 & 6.95 & 16.37 & 22.25 & 12.72 & 22.99 & 1.96 & 1.75 \\
\hline \multirow[t]{2}{*}{$\mathrm{LSD}_{0.05}$} & I factor & 0.082 & 5.656 & 0.058 & 0.058 & 0.139 & 0.245 & 0.192 & 0.158 & 0.101 & 0.165 \\
\hline & II factor & 0.042 & 2.880 & 0.030 & 0.029 & 0.071 & 0.125 & 0.098 & 0.080 & 0.051 & 0.084 \\
\hline \multirow[t]{2}{*}{ Interaction } & I / II & 0.115 & 7.999 & 0.082 & 0.082 & 0.197 & 0.346 & 0.271 & 0.223 & 0.142 & n.s. \\
\hline & II / I & 0.083 & 5.759 & 0.059 & 0.059 & 0.142 & 0.249 & 0.195 & 0.161 & 0.102 & n.s. \\
\hline$S D$ & & 5.36 & 9.90 & 1.03 & 2.87 & 3.14 & 12.46 & 1.00 & 18.94 & 0.97 & 0.27 \\
\hline
\end{tabular}

n.s. - not significant.

TABLE 3. Available forms of heavy metals $\left(\mathrm{mg} \cdot \mathrm{kg}^{-1}\right)$

\begin{tabular}{|c|c|c|c|c|c|c|c|c|c|c|c|}
\hline \multirow{2}{*}{$\begin{array}{l}\text { Objects } \\
\text { I factor }\end{array}$} & \multirow{2}{*}{$\begin{array}{l}\text { Depth } \\
\text { (cm) } \\
\text { II factor }\end{array}$} & \multicolumn{2}{|l|}{$\mathrm{Zn}$} & \multicolumn{2}{|l|}{$\mathrm{Cu}$} & \multicolumn{2}{|l|}{$\mathrm{Pb}$} & \multicolumn{2}{|l|}{$\mathrm{Ni}$} & \multicolumn{2}{|l|}{$\mathrm{Cd}$} \\
\hline & & 2012 & 2013 & 2012 & 2013 & 2012 & 2013 & 2012 & 2013 & 2012 & 2013 \\
\hline \multirow[t]{2}{*}{$\mathrm{C}$} & $0-15$ & 2.56 & 3.16 & 1.53 & 1.24 & 0.46 & 0.55 & 9.14 & 9.82 & 0.81 & 1.07 \\
\hline & $15-30$ & 2.40 & 2.27 & 1.33 & 1.12 & 0.55 & 0.31 & 6.73 & 8.09 & 0.78 & 1.18 \\
\hline \multirow[t]{2}{*}{$\mathrm{E}$} & $0-15$ & 10.3 & 6.09 & 2.33 & 1.62 & 0.91 & 0.87 & 12.06 & 8.09 & 0.89 & 1.17 \\
\hline & $15-30$ & 3.93 & 3.04 & 1.29 & 0.98 & 0.59 & 0.69 & 7.70 & 7.05 & 0.84 & 1.27 \\
\hline \multirow[t]{2}{*}{ A } & $0-15$ & 7.59 & 11.53 & 2.29 & 1.92 & 1.10 & 16.43 & 11.57 & 9.56 & 0.63 & 1.29 \\
\hline & $15-30$ & 3.68 & 3.46 & 1.33 & 1.45 & 0.64 & 7.26 & 6.82 & 7.27 & 0.60 & 1.39 \\
\hline \multirow[t]{2}{*}{ B } & $0-15$ & 5.37 & 14.09 & 1.57 & 3.15 & 0.82 & 1.05 & 9.36 & 10.48 & 0.83 & 1.37 \\
\hline & $15-30$ & 2.67 & 2.80 & 1.65 & 1.24 & 0.64 & 0.73 & 10.89 & 5.58 & 0.98 & 1.45 \\
\hline Mean & & 4.82 & 5.83 & 1.61 & 1.60 & 0.73 & 3.50 & 9.30 & 8.25 & 0.80 & 1.29 \\
\hline \multirow[t]{2}{*}{$\mathrm{LSD}_{0.05}$} & I factor & 0.032 & 0.202 & n.s. & 0.075 & 0.070 & 0.060 & 0.145 & 0.067 & 0.062 & 0.047 \\
\hline & II factor & 0.016 & 0.103 & 0.281 & 0.038 & 0.036 & 0.031 & 0.074 & 0.034 & n.s. & 0.024 \\
\hline \multirow[t]{2}{*}{ Interaction } & I / II & 0.045 & 0.286 & n.s. & 0.106 & 0.100 & 0.085 & 0.205 & 0.095 & 0.087 & n.s. \\
\hline & II / I & 0.033 & 0.206 & n.s. & 0.076 & 0.072 & 0.061 & 0.148 & 0.068 & 0.063 & n.s. \\
\hline$S D$ & & 2.82 & 4.52 & 0.42 & 0.70 & 0.21 & 5.71 & 2.18 & 1.64 & 0.13 & 0.13 \\
\hline
\end{tabular}

n.s. - not significant. 
of total $\mathrm{Cd}$ were also found in the surface horisons were noted in the soil sampled from the border area (E) but only in 2012. Bogacz et al. (2011), in the post-fire areas used as forests and meadows, found a varied effect of fire on the content of some heavy metals. The contents of $\mathrm{Zn}, \mathrm{Pb}$ and $\mathrm{Cd}$ increased due to fire, while the content of $\mathrm{Cu}$ did not change. The concentration of metals was observed mostly in surface horizons. The pools of those metals in forest soils were lower than in meadow soils and soil reaction was favourable to metal concentration. In the present study the relation with the soil $\mathrm{pH}$ was found only for the content of total forms of nickel a year after the fire $(r=0.748, p<0.05)$ (Table 7). The analysis of correlation, however, confirmed a significant positive dependence between the content of total forms of $\mathrm{Zn}$, $\mathrm{Cu}, \mathrm{Pb}$ and $\mathrm{Ni}$ and total organic carbon in the soil sampled in 2012 (Table 7), which can be due to the accumulation of metals related to the amount of carbon in ashes produced during fire. Over the first months after the fire the concentrations of heavy metals in soil can exceed the permitted content limits. In this study the concentration of metals did not exceed the norms provided for in Regulation of the Minister Polish of the Environment (Dz.U. No. 165, item. 1359. 2002, Dz. U. item. 1395. 2016). The soil samples analysed can be thus considered unpolluted.
Mobility and availability of metals is controlled by many chemical and biochemical processes which occur in soils. Not all of them are of the same importance for each metal. Soil reaction is a decisive parameter. The analysis of correlation identified only significant positive dependencies between soil reaction and the content of available lead forms in both years of analysis $(\mathrm{r}=0.871, \mathrm{p}<0.05$ and $\mathrm{r}=$ $0.855, \mathrm{p}<0.05$, respectively) (Table 7). Garcia-Marco and Gonzalez-Prieto (2008), investigating short- and medium-term effects of fire in terms of the availability of microelements in soil, have identified that even an inconsiderable soil $\mathrm{pH}$ increase due to fire was enough to decrease the availability of some microelements. In 2012 an increase in soil $\mathrm{pH}$ at the sites caught by fire was related, as for some metals analysed, to a decrease in the content of their available forms. However, it was not confirmed by the analysis of of correlation. Yet the analysis of correlation demonstrated, similarly as for total forms, significant positive dependencies between the content of available forms of $\mathrm{Zn}, \mathrm{Cu}, \mathrm{Pb}$ and $\mathrm{Ni}$, and the content of organic carbon (Table 7). Determining the admissible limits of the content of available forms in terms of their phytotoxicity, it was found that for $\mathrm{Zn}, \mathrm{Cu}$ and $\mathrm{Ni}$, they were not exceeded (Korzeniowska and Stanisławska-Glubiak 2003). To evaluate the availability of heavy metals, availability factor $(A F)$ was applied.

TABLE 4. Available factors $(A F \%)$

\begin{tabular}{|c|c|c|c|c|c|c|c|c|c|c|c|}
\hline \multirow[t]{2}{*}{ Objects } & \multirow{2}{*}{$\begin{array}{l}\text { Depth } \\
(\mathrm{cm})\end{array}$} & \multicolumn{2}{|l|}{$\mathrm{Zn}$} & \multicolumn{2}{|l|}{$\mathrm{Cu}$} & \multicolumn{2}{|l|}{$\mathrm{Pb}$} & \multicolumn{2}{|l|}{$\mathrm{Ni}$} & \multicolumn{2}{|l|}{$\mathrm{Cd}$} \\
\hline & & 2012 & 2013 & 2012 & 2013 & 2012 & 2013 & 2012 & 2013 & 2012 & 2013 \\
\hline \multirow[t]{2}{*}{$\mathrm{C}$} & $0-15$ & 20.08 & 25.48 & 24.48 & 21.66 & 54.24 & 50.15 & 3.35 & 4.24 & 29.19 & 65.85 \\
\hline & $15-30$ & 20.69 & 21.57 & 20.08 & 20.36 & 48.07 & 52.96 & 4.78 & 2.57 & 28.11 & 90.77 \\
\hline \multirow[t]{2}{*}{ E } & $0-15$ & 39.24 & 37.19 & 26.33 & 22.34 & 57.02 & 48.81 & 6.55 & 5.62 & 28.94 & 69.85 \\
\hline & $15-30$ & 30.82 & 24.47 & 20.08 & 16.47 & 54.47 & 50.90 & 4.96 & 5.55 & 30.27 & 90.71 \\
\hline \multirow[t]{2}{*}{ A } & $0-15$ & 35.51 & 43.63 & 27.67 & 28.98 & 59.11 & 26.79 & 8.15 & 25.46 & 66.49 & 67.89 \\
\hline & $15-30$ & 24.21 & 26.77 & 22.35 & 24.37 & 55.56 & 49.37 & 5.49 & 32.48 & 64.52 & 80.58 \\
\hline \multirow[t]{2}{*}{ B } & $0-15$ & 29.18 & 36.34 & 21.22 & 22.83 & 55.06 & 75.57 & 6.20 & 2.93 & 63.95 & 66.02 \\
\hline & $15-30$ & 23.37 & 23.63 & 24.44 & 26.11 & 64.06 & 53.24 & 5.31 & 9.51 & 91.12 & 73.42 \\
\hline
\end{tabular}

TABLE 5. Index of changes in time (TI) for heavy metals

\begin{tabular}{|c|c|c|c|c|c|c|c|c|c|c|c|}
\hline \multirow[t]{2}{*}{ Objects } & \multirow{2}{*}{$\begin{array}{l}\text { Depth } \\
(\mathrm{cm})\end{array}$} & \multicolumn{2}{|l|}{$\mathrm{Zn}$} & \multicolumn{2}{|l|}{$\mathrm{Cu}$} & \multicolumn{2}{|l|}{$\mathrm{Pb}$} & \multicolumn{2}{|l|}{$\mathrm{Ni}$} & \multicolumn{2}{|l|}{$\mathrm{Cd}$} \\
\hline & & Tot. & Av. & Tot. & Av. & Tot. & Av. & Tot. & Av. & Tot. & Av. \\
\hline \multirow[t]{2}{*}{$\mathrm{C}$} & $0-15$ & 0.97 & 1.23 & 0.92 & 0.81 & 1.18 & 1.07 & 0.94 & 1.20 & 0.59 & 1.32 \\
\hline & $15-30$ & 0.91 & 0.95 & 0.83 & 0.84 & 1.09 & 1.20 & 1.05 & 0.56 & 0.47 & 1.51 \\
\hline \multirow[t]{2}{*}{$\mathrm{E}$} & $0-15$ & 0.62 & 0.59 & 0.82 & 0.70 & 0.78 & 0.67 & 1.11 & 0.96 & 0.54 & 1.31 \\
\hline & $15-30$ & 0.97 & 0.77 & 0.93 & 0.76 & 1.08 & 0.92 & 1.30 & 1.17 & 0.50 & 1.51 \\
\hline \multirow[t]{2}{*}{$\mathrm{A}$} & $0-15$ & 1.24 & 1.52 & 0.80 & 0.84 & 1.82 & 0.83 & 4.78 & 14.93 & 2.02 & 1.37 \\
\hline & $15-30$ & 0.85 & 0.94 & 1.00 & 1.09 & 1.20 & 1.07 & 1.92 & 11.34 & 1.85 & 1.49 \\
\hline \multirow[t]{2}{*}{ B } & $0-15$ & 2.11 & 2.62 & 1.86 & 2.01 & 2.79 & 1.12 & 2.71 & 1.28 & 1.61 & 1.06 \\
\hline & $15-30$ & 1.04 & 1.05 & 0.70 & 0.75 & 0.85 & 0.51 & 2.97 & 1.14 & 1.85 & 1.36 \\
\hline
\end{tabular}

Tot. - total forms, Av. - available forms. 
As for lead and cadmium, the factor values were very high, irrespective of the soil sampling location and the year of analysis (Table 4). The calculated values of the coefficient of availability for the metals analysed were as follows: $\mathrm{Pb}>\mathrm{Cd}>\mathrm{Zn}>\mathrm{Cu}>\mathrm{Ni}$ and pointed to a greater availability of nickel and cadmium than that of zinc and copper. An unfavourable behaviour of the metals analysed is related to soil reaction and the content of organic carbon. Those two parameters are essential for the control of the availability of microelements, directly affecting their solubility (Obrador et al. 2007, Diatta et al. 2014).

Time index (index of changes in time-TI) presents changes in the content of the metals analysed in soil throughout the year. The highest values for most metals analysed were reported in surface horizons of site B (Table 5). Literature reports confirm a slight increase in the content of total and bioavailable forms of heavy metals in soils exposed to fires (Stancov Jovanovic et al. 2011, Mitic et al. 2015).

One of the most important enzymes defending organisms against negative effects of oxidative stress is catalase. According to Brzezińska (2006), catalase released from cells shows a considerable stability thanks to sorption by clay minerals and organic substance thus reducing its activity. The results of the ANOVA (Table 6) showed a significant effect of both sites and depth on the changes in activity of catalase in the soil. The highest activity of CAT $0.402 \mathrm{mg} \mathrm{H}_{2} \mathrm{O}_{2}$ $\mathrm{g}^{-1} \mathrm{~min}^{-1}$ for $15-30 \mathrm{~cm}$ was obtained in the soil collected from the site (A) (2012) while in 2013 in site $\mathrm{B}\left(0.431 \mathrm{mg} \mathrm{H}_{2} \mathrm{O}_{2} \mathrm{~g}^{-1} \mathrm{~min}^{-1}\right.$ for $\left.15-30 \mathrm{~cm}\right)$. Gömöryová et al. (2008) also report on a variation in the activity of the enzyme (cellulase) depending on how far the location was from fire. There was shown no effect of heavy metals on the activity of soil catalase, which must have been related to non-exceeding the norms of their concentration.

With the positive values of $T I$ index (except for the soil sampled from location A $0-15 \mathrm{~cm}$ ) an increase in activity a year after fire was found, which shows that soil of both layers received the state of relative dynamic biological equilibrium, indispensable for the right operation of forest ecosystem.

The activity of catalase in the soil sampled in 2012 from horizon $0-15 \mathrm{~cm}$ of point $\mathrm{B}$ got most inhibited (RCh-12.71\%), as compared with the control, similarly as a year after fire $(R C h-13.24 \%)$.

TABLE 6 . The activity of catalase $\left(\mathrm{mg} \mathrm{H}_{2} \mathrm{O}_{2} \mathrm{~g}^{-1} \mathrm{~min}^{-1}\right)$ and index of changes in time $(T I)$, resistance $(R S)$ and relative changes $(R C h)$ of activity the catalase in soil

\begin{tabular}{|c|c|c|c|c|c|c|c|c|}
\hline \multirow{2}{*}{$\begin{array}{l}\text { Objects } \\
\text { I factor }\end{array}$} & \multirow{2}{*}{$\begin{array}{l}\text { Depth }(\mathrm{cm}) \\
\text { II factor }\end{array}$} & \multirow[t]{2}{*}{2012} & \multirow[t]{2}{*}{2013} & \multirow[t]{2}{*}{ TI } & \multicolumn{2}{|l|}{$R S$} & \multicolumn{2}{|c|}{$R C h[\%]$} \\
\hline & & & & & 2012 & 2013 & 2012 & 2013 \\
\hline \multirow[t]{2}{*}{$\mathrm{C}$} & $0-15$ & 0.346 & 0.385 & 1.10 & - & - & - & - \\
\hline & $15-30$ & 0.334 & 0.368 & 1.19 & - & - & - & - \\
\hline \multirow[t]{2}{*}{ E } & $0-15$ & 0.310 & 0.368 & 1.28 & 0.81 & 0.93 & -10.41 & -4.42 \\
\hline & $15-30$ & 0.295 & 0.376 & 1.20 & 0.79 & 0.96 & -11.67 & 2.17 \\
\hline \multirow[t]{2}{*}{ A } & $0-15$ & 0.328 & 0.394 & 0.99 & 0.90 & 0.95 & -5.20 & 2.34 \\
\hline & $15-30$ & 0.402 & 0.397 & 1.11 & 0.66 & 0.85 & 20.36 & 7.88 \\
\hline \multirow[t]{2}{*}{ B } & $0-15$ & 0.302 & 0.334 & 1.21 & 0.77 & 0.77 & -12.71 & -13.24 \\
\hline & $15-30$ & 0.356 & 0.431 & 1.14 & 0.87 & 0.71 & 6.59 & 17.12 \\
\hline Mean & & 0.335 & 0.382 & & & & & \\
\hline \multirow[t]{2}{*}{$\mathrm{LSD}_{0.05}$} & I factor & 0.006 & 0.006 & & & & & \\
\hline & II factor & 0.003 & 0.003 & & & & & \\
\hline \multirow[t]{2}{*}{ Interaction } & $\mathrm{I} / \mathrm{II}$ & 0.009 & 0.009 & & & & & \\
\hline & II/I & 0.006 & 0.006 & & & & & \\
\hline$S D$ & & 0.034 & 0.028 & & & & & \\
\hline
\end{tabular}

TABLE 7. Pearson's correlation coefficients $(\mathrm{p}<0.05)$

\begin{tabular}{|c|c|c|c|c|c|c|c|c|}
\hline \multirow[t]{2}{*}{ Parameters } & \multicolumn{2}{|l|}{$\mathrm{Zn}$} & \multicolumn{2}{|l|}{$\mathrm{Cu}$} & \multicolumn{2}{|l|}{$\mathrm{Pb}$} & \multicolumn{2}{|l|}{$\mathrm{Ni}$} \\
\hline & Tot. & Av. & Tot. & Av. & Tot. & Av. & Tot. & Av. \\
\hline \multicolumn{9}{|l|}{ Year 2012} \\
\hline TOC & 0.902 & 0.871 & 0.885 & 0.897 & 0.926 & 0.764 & 0.891 & 0.865 \\
\hline $\mathrm{pH}_{\mathrm{KCl}}$ & n.s. & n.s. & n.s. & n.s. & n.s. & 0.871 & n.s. & n.s. \\
\hline \multicolumn{9}{|l|}{ Year 2013} \\
\hline $\mathrm{pH}_{\mathrm{KCl}}$ & n.s. & n.s. & n.s. & n.s. & n.s. & 0.855 & 0.748 & n.s. \\
\hline
\end{tabular}

Tot. - total forms, Av. - available forms, n.s. - not significant. 
Resistance of soil $(R S)$ is an effective measure of activity of some enzymes responses to environmental stress (Orwin and Wardle 2004, Borowik et. al 2014). The values of resistance of soil for the activity of catalase were positive throughout the study. However they differed depending on the place of sampling, depth as well as the years in which the research was conducted (Table 6). The authors of the index (Orwin and Wardle 2004) report on the $R S$ values falling within the range from -1 to 1 , where 1 stands for a lack of the effect of human impact on the environment. Lower $R S$ values in 2012, as compared to 2013, point to a negative effect of fire on selected parameters (this does not apply to point B).

To determine the nature and strength of dependencies between the parameters in 2012 and 2013, the method of principal component analysis (PCA) was applied. A projection of the variables on the factor-plane clearly demonstrated correlations between some soil properties and catalase activity (Fig. 1). In 2012 two principal factors had a significant total
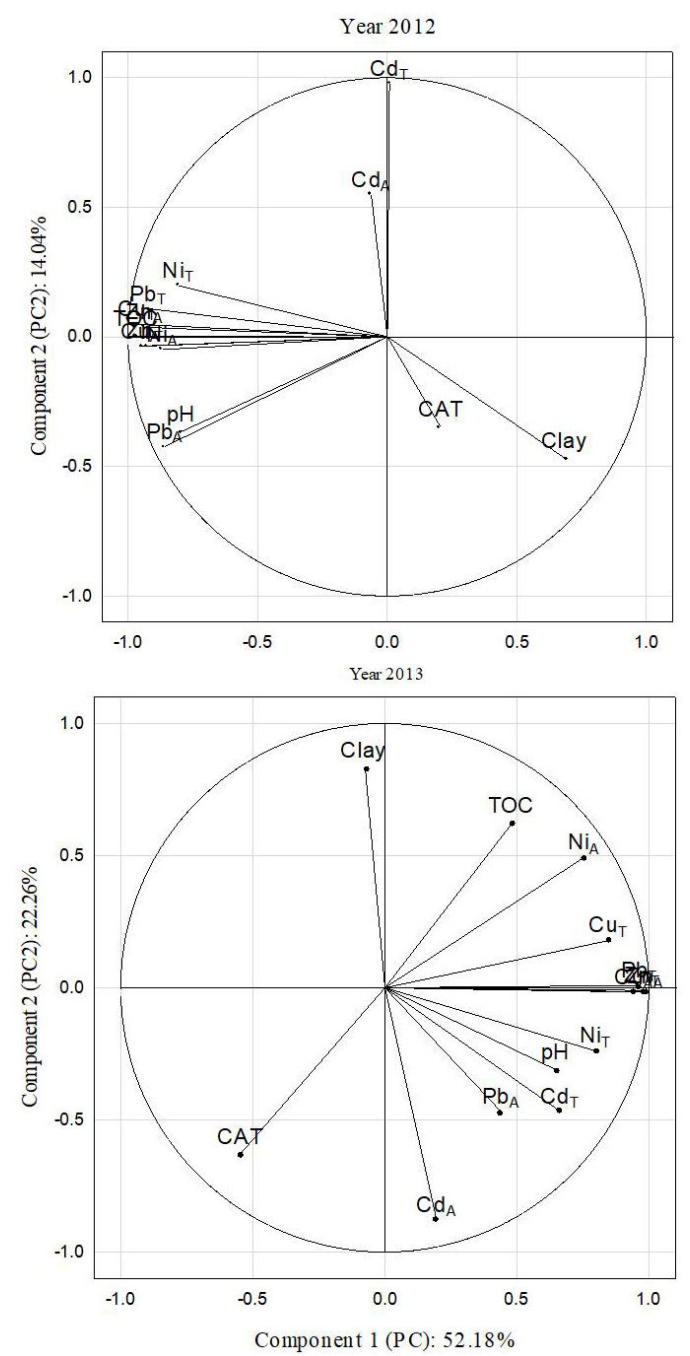

FIGURE 1. Projection of the variables on the factor-plane in soils impact $(75.9 \%)$ on the variance of the variables. It was found that most variance was included in the first principal component (PC1). Component 1 (PC1) accounted for $61.9 \%$ of the variance of the properties. Both TOC, total content of $\mathrm{Zn}, \mathrm{Cu}, \mathrm{Pb}$ and available form of $\mathrm{Zn}$ and $\mathrm{Cu}$ content had a major negative effect on PC1 ( $>-0.900)$ (Table 8). Moreover, total content of nickel and available forms of lead and nickel had a major negative effect on PC1 (>-0.800). In the soils sampled right after fire an immobilization of almost all heavy metals (except for total and available forms of Cd) was identified. Negative values had a negative effect on the source of variation in parameters. That dependence strongly suggests that the variables have a similar source (fire). Most heavy metals were strongly positively correlated with the content of TOC. The share of the second principal component (PC2) (14.04\%) showed only a positive correlation (0.977) with the total cadmium form. In 2013 there were found positive correlations with total forms of most metals analysed ( $\mathrm{Zn}, \mathrm{Cu}, \mathrm{Pb}, \mathrm{Ni})$ and available form of $\mathrm{Zn}$ and $\mathrm{Cu}$ with the first principal component (PC1) which accounted for $52.17 \%$ of variation, while the second principal component (PC2) revealed a positive correlation with clay fraction (0.831), and a negative correlation for available forms $\mathrm{Cd}(-0.878)$.

To determine the similarities between soils sampled from 4 sites (2 depths) in two research years (2012 and 2013), Ward's method (1963) was applied, based on soil properties (clay, $\mathrm{pH}_{\mathrm{KCl}}$, TOC), the contents of total and available heavy metals $(\mathrm{Zn}, \mathrm{Cu}, \mathrm{Pb}, \mathrm{Ni}, \mathrm{Cd})$ and the activity of catalase (CAT). In 2012 the clustering procedure facilitated differentiating three

TABLE 8. Values of the two extracted factor loadings for 14 elements

\begin{tabular}{|c|c|c|c|c|}
\hline \multirow[t]{2}{*}{ Parameters } & \multicolumn{2}{|c|}{ Year 2012} & \multicolumn{2}{|c|}{ Year 2013} \\
\hline & PC1 & PC2 & PC1 & $\mathrm{PC} 2$ \\
\hline Clay & 0.688 & -0.470 & -0.074 & $0.831^{*}$ \\
\hline TOC & $-0.967 *$ & 0.001 & 0.481 & 0.622 \\
\hline $\mathrm{pH}$ & $-0.794 *$ & -0.365 & 0.647 & -0.309 \\
\hline $\mathrm{Zn}_{\text {Tot. }}$ & $-0.933^{*}$ & -0.034 & $0.975 *$ & 0.009 \\
\hline $\mathrm{Cu}_{\mathrm{Tot}}^{\text {lot. }}$ & $-0.965^{*}$ & 0.049 & $0.847 *$ & 0.178 \\
\hline $\mathrm{Pb}_{\mathrm{Tot}}$ & $-0.921 *$ & 0.109 & $0.963 *$ & 0.008 \\
\hline $\mathrm{Ni}_{\text {Tot }}^{\text {lot. }}$ & $-0.806^{*}$ & 0.197 & $0.799 *$ & -0.239 \\
\hline $\mathrm{Cd}_{\text {Tot. }}$ & 0.008 & $0.977 *$ & 0.663 & 0.467 \\
\hline $\mathrm{Zn}_{\mathrm{Av}}$ & $-0.937^{*}$ & 0.037 & $0.987 *$ & 0.014 \\
\hline $\mathrm{Cu}_{\mathrm{Av}}$ & $-0.952 *$ & -0.036 & $0.944 *$ & 0.015 \\
\hline $\mathrm{Pb}_{\mathrm{Av}}$ & $-0.859 *$ & -0.423 & 0.439 & 0.468 \\
\hline $\mathrm{Ni}_{\mathrm{Av}}$ & $-0.867 *$ & -0.048 & 0.753 & 0.493 \\
\hline $\mathrm{Cd}_{\mathrm{AV}}$ & 0.061 & 0.546 & 0.196 & $-0.878^{*}$ \\
\hline CAT & 0.203 & -0.345 & -0.551 & 0.632 \\
\hline Variation (\%) & 61.90 & 14.04 & 52.17 & 14.13 \\
\hline Eigenvalue & 8.667 & 1.965 & 7.304 & 1.978 \\
\hline
\end{tabular}

Tot. - total forms, Av. - available forms, * statistically significant. 

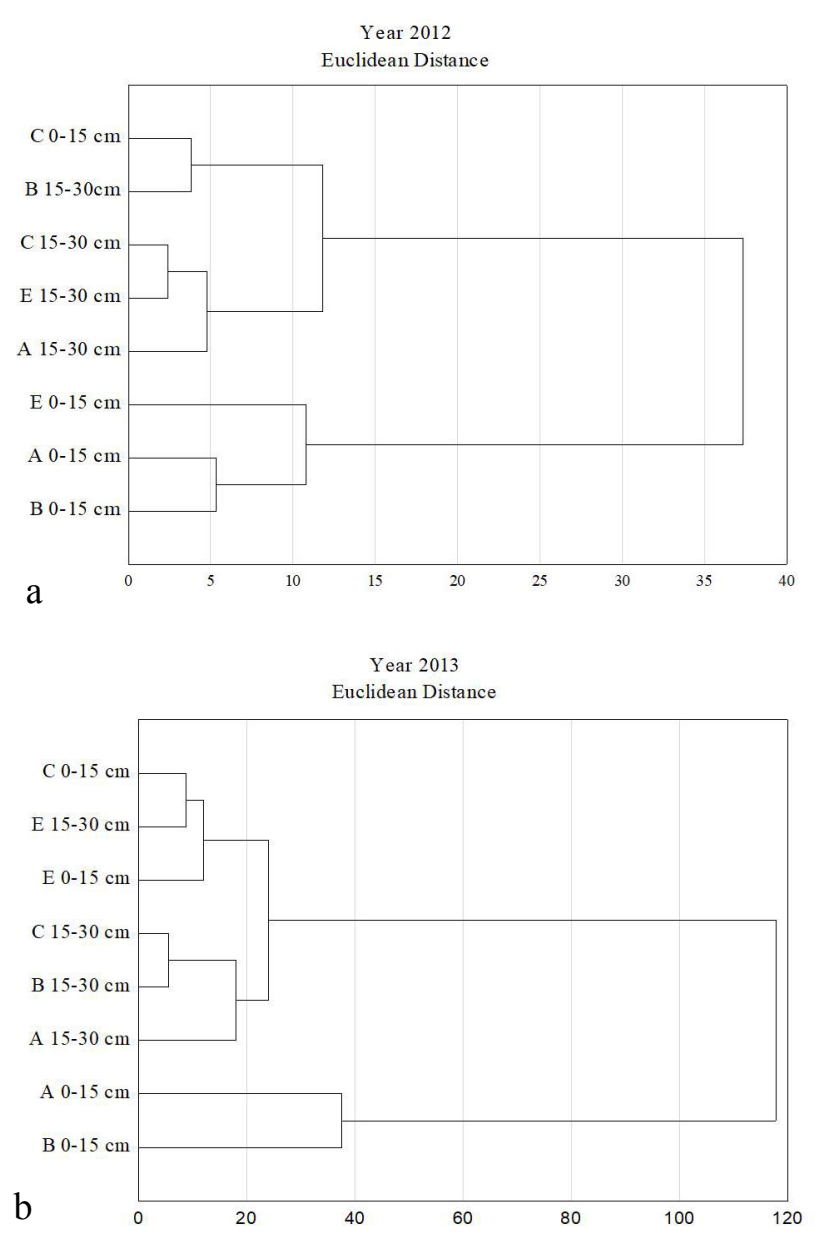

FIGURE 2. Dendrogram analysis of some physicochemical parameters (clay fraction, TOC, pH, ZnTot. CuTot., PbTot., NiTot., CdTot., ZnAv., CuAv., PbAv., NiAv., CdAv., CAT) in soil

clusters of soils with similar properties, content of heavy metals and CAT (Fig. 2a). Cluster 1 groups soils from site $\mathrm{C}_{0-15 \mathrm{~cm}}$ and $\mathrm{B}_{15-30 \mathrm{~cm}}$. Cluster 2 groups soils from $C, E$ and $A$ from the depth of $0-15 \mathrm{~cm}$, while cluster 3 includes soils E, A and B from the depth of $0-15 \mathrm{~cm}$. In 2013 also 3 clusters were separated; however, they were differently clustered than in 2012 (Fig. 2b). Cluster 1 consisted of soils from site $\mathrm{C}_{0-15 \mathrm{~cm}}, \mathrm{E}_{0-15 \mathrm{~cm}}, \mathrm{E}_{15-30 \mathrm{~cm}}$ and cluster 2- soils from sites $\mathrm{C}, \mathrm{A}$ and $\mathrm{B}$ from the depth of $15-30 \mathrm{~cm}$, whereas cluster 3 - soils A and B from the depth of $0-15$ $\mathrm{cm}$. The clustering analysis demonstrated similarities of soils of the forest ecosystem sites under study. Differences in clustering the sites in years were identified, which was related to the effect of fire on the soil parameters.

\section{CONCLUSION}

The research has shown a significant effect of fire on the contents of the heavy metals under study. Both the distance from ecotone and soil sampling depth had a significant on changes of the parameters. Fire did not cause a rapid increase in the content of heavy metals. The concentrations of total metal forms did not exceed the norms provided for in Regulation of the Minister of the Environment. The soil analysed can be considered unpolluted with those metals. The calculated availability factor $(A F)$ showed an unfavourable higher availability of lead and cadmium than zinc and copper. With the calculated values of time index (TI), no unambiguous changes in the content of heavy metals were identified. Fire changed the activity of catalase significantly. Only in surface horisons of soil the $R C h$ index value showed the highest inhibition of catalase in soil from the site $200 \mathrm{~m}$ away from the ecotone (only in surface layers of soil). In the soil a year after fire the enzyme got activated, which was confirmed by a positive $T I$ value.

\section{ACKNOWLEDGEMENT}

The authors would like to thank the Faculty of Agriculture and Biotechnology, UTP University of Science and Technology in Bydgoszcz for their support for this research work.

\section{REFERENCES}

Aref I.M., Atta H.A., Ghamade A.R., 2011. Effect of forest fires on tree diversity and some soil properties. International Journal of Agriculture and Biology 13: 659-664.

Bogacz A., Łabaz B., Woźniczka P., 2013. Impact of fire on values of organic material transformation indicators. Roczniki Gleboznawcze - Soil Science Annual 64(3): 88-92. DOI: 10.2478/ ssa-2013-0013.

Bogacz A., Woźniczka P., Łabaz B., 2011. Concentration and pools of heavy metals in organic soils in post-fire areas used as forests and meadows. Journal of Elementology 16(4): 515524. DOI: $10.5601 /$ jelem.2011.16.4.01.

Borowik A., Wyszkowska J., Kucharski, J., Baćmaga M., BorosLajszner E., Tomkiel M., 2014. Sensitivity of soil enzymes to excessive zinc concentrations. Journal of Elementology 19(3): 637-648.

Brais S., David P., Quimer R., 2000. Impacts of wild fire severity and salvage harvesting on the nutrient balance of jack pine and black spruce boreal stands. Forest Ecology and Management 137(1): 231-243.

Brzezińska M., 2006. Impact of treated wastewater on biological activity and accompanying processes in organic soils. Acta Agrophysica, Rozprawy i Monografie 2(131): 1-164. 
Carter M.C., Foster C.L., 2004. Prescribed burning and productivity in southern pine forest: a review. Forest Ecology and Management 191(1): 93-109.

Certini G., 2005. Effect of fire on properties of soil - A review. Oecologia 143(1): 1-10.

Chaer G., Fernandes M., Myrold D., Bottomley P., 2009. Comparative resistance and resilience of soil microbial communities and enzyme activities in adjacent native forest and agricultural soils. Microbial Ecology 58(2): 414-424.

Clark B., 2001. Soils, water, and watersheds. [In:] Fire Effects Guide. National Interagency Fire Center 2394: 93-109.

Crock J.G., Severson R., 1980. Four reference soil and rock samples for measuring element availability in the western energy regions. Geochemical Survey Circular 841: 1-16.

DeBano L.F., 2000. The role of fire and soil heating on water repellency in wild and environments: a review. Journal Hydrology 231: 195-206.

Diatta J., Grzebisz W., Frąckowiak-Pawlak K., Andrzejewska A., Brzykcy M., 2014. Site-specific evaluation of $\mathrm{Cu}, \mathrm{Zn}, \mathrm{Fe}$ and Mn availability in arable soil. Zemdirbyste-Agriculture 101(3): 235-242. DOI: 10.13080/z-a.2014.101.030.

Dz.U. No.165 item 1359. 2002. Regulation of the Minister of Environment dated 9 September 2002 on standards of soil quality and land quality standards (in Polish).

Dz.U. item. 1395. 2016. Regulation of the Minister of the Environment dated 1 September 2016 on assessment procedures for the land surface pollution (in Polish).

Ekinci H., 2006. Effect of forest fire on some physical, chemical and biological properties of soil in Çanakkale, Turkey. International Journal of Agriculture and Biology 8(1): 102-106.

Gömöryová E., Stř̌elcová K., Škvarenina J., Bebej J., Gömöry D., 2008. The impact of windthrow and fire disturbances on selected soil properties in the Tatra National Park Soil Water Research 3(1): 74-80.

Gonet S.S., Dziadowiec H., Bućko M., 2009. Profile morphology, chemical properties and organic matter stocks in soils after pine forest fire. Roczniki Gleboznawcze - Soil Science Annual 60(2): 32-38.

García-Marco S., González-Prieto S., 2008. Short- and mediumterm effects of fire and firefighting chemicals on soil micronutrient availability. Science of the Total Environment 407(1): 297-303.

Hamman S.T., Burke I.C., Knapp E.E., 2008. Soil nutrients and microbial activity after early and late season prescribed burns in a Sierra Nevada mixed conifer forest. Forest Ecology and Management 256(3): 367-374.

DOI:10.1016/j.foreco.2008.04.030

Iglesias T., Cala V., Gonzales J., 1997. Mineralogical and chemical modifications in soils affected by a forest lire in the Mediterranean area. Science of the Total Environment 204(1): 8996.

Januszek K., Lasota J., Gruba P., Domicz G., 2001. Właściwości fizyczno-chemiczne i biochemiczne gleb bielicowych sześć lat po pożarze całkowitym lasu. Acta Agraria et Silvestria series Silvestris 39: 47-61 (in Polish).

Johnson J.I., Temple K.L., 1964. Some variables affecting the measurements of catalase activity in soil. Soil Science Society of America Journal 28(2): 207-216.
Korzeniowska J., Stanisławska-Glubiak E., 2003. Phytotoxic concentration of some heavy metals in soil. Advances of Agricultural Sciences Problem Issues 493: 167-173.

Lemanowicz J., Bartkowiak A., 2015. Effect of scots pine forest fire of carbon, phosphorus and phosphatases activity in soil. Baltic Forestry 21(2): 369-374.

Lemanowicz J., Krzyżaniak M., 2015. Vertical distribution of phosphorus concentrations, phosphatase activity and further soil chemical properties in salt-affected Mollic Gleysols in Poland. Environmental Earth Science 74(3): 2719-2728. DOI: $10.1007 / \mathrm{s} 12665-015-4294-x$.

Miesel J.R., Goebel P.C., Corace R.G., Hix D.M., Kolka R., Palik B., Mladenoff D., 2012. Fire effects on soils in Lake States Forests: A Compilation of published research to facilitate long-term investigations. Forests 3(4): 1034-1070. DOI: $10.3390 / \mathrm{f} 3041034$

Mitic V.D., Stancov Jovanovic V.P., Ilic M.D., Nicolic Mandic S.D., 2015. Impact of wildfire on soil characteristics on some metal content in selected plants species of Geraniaceae family. Environmental Earth Sciences 73(8): 4581-4594.

DOI: $10.1007 / \mathrm{s} 12665-014-3744-1$.

Obrador A., Alvarez J.M., Lopez-Valdivia L.M., Gonzalez D., Novillo J., Rico M.I., 2007. Relationships of soil properties with $\mathrm{Mn}$ and $\mathrm{Zn}$ distribution in acidic soils and their uptake by a barley crop. Geoderma 137(3-4): 432-443. DOI: $10.1016 /$ j. geoderma.2006.10.001.

Olszowska G., 2009. Enzyme activity of soils after large-scale fires under varying habitat conditions using different methods of forest regeneration. Forest Research Papers 70(2): 183188. DOI:10.2478/v10111-009-0018-x.

Orwin K.H., Wardle D.A., 2004. New indices for quantifying the resistance and resilience of soil biota to exogenous disturbances. Soil Biology and Biochemistry 36(11): 1907-1912. DOI:10.1016/j.soilbio.2004.04.036.

PN-ISP 10381-2:2007P. 2007. Soil quality - Sampling - Part 2: Guidance on sampling techniques.

Prędecka A., Chojnicki J., Russel S., 2010. The effect of spring grass burning on the bacteria count and the soil dehydrogenases activity. Science Nature Technologies 4(6): 93.

Schafer J.L., Mack M.C., 2010. Short-term effects of fire on soil and plant nutrients. Plant Soil 334(1-2): 433-447.

Stancov Janovic V.P., Ilic M.D., Marcovic M.S., Mitic V.D., Nikolic Mondic S.D., Stojanovic G.S., 2011. Wild fire impact on copper, zinc, lead and cadmium distribution in soil and relation with abundance in selected plants of Lamiaceae family from Vidlic Mountain (Serbia). Chemosphere 84(11): 1584-1591. DOI:10.1016/j.chemosphere.2011.05048.

Verma S., Jayakumar S., 2012. Impact of forest fire on physical, chemical and biological properties of soil: A review. Proceedings of the International Academy of Ecology and Environmental Sciences 2(3): 168-176.

Wang B., Xue S., Liu G.B., Li G., Ren Z.P., 2012. Changes in soil nutrient and enzyme activities under different vegetations in the Loess Plateau area, Northwest China. Catena 92: 186-195.

Ward J.H., 1963. Hierarchical grouping to optimize an objective function. Journal American Statistical Association 58(301): 236-244.

Received: April 5, 2017

Accepted: August 29, 2017

Associated editor: J. Lasota 


\section{Oddziaływanie pożaru lasu na zmiany zawartości form calkowitych i przyswajalnych wybranych metali ciężkich oraz aktywności katalazy w glebie}

Streszczenie: Celem pracy była ocena wpływu pożaru lasu na zawartość form całkowitych i przyswajalnych cynku, miedzi, ołowiu, niklu i kadmu oraz aktywności katalazy w glebie. Badania przeprowadzono bezpośrednio (2012 rok) i rok po pożarze (2013 rok). Pożar wpłynął istotnie na zawartość analizowanych metali ciężkich w poziomach powierzchniowych, ale nie spowodował gwałtownego ich wzrostu. Odnotowane stężenia form całkowitych metali nie przekroczyły norm przyjętych w Rozporządzeniu Ministra Środowiska. Analizowane próbki glebowe można zaliczyć do niezanieczyszczonych tym metalami. Wyliczone współczynniki przyswajalności wykazały niekorzystną wyższą dostępność ołowiu i kadmu nad cynkiem i miedzią. Analiza statystyczna wykazała istotny wpływ pożaru na kształtowanie się aktywności katalazy. Wskaźnik oporności $(R S)$ dla katalazy wykazał niższe wartości w roku 2012 w porównaniu do roku 2013 (za wyjątkiem gleb ze stanowiska B). Obliczone wartości współczynnika zmienności w czasie $(T I)$ świadczyły o aktywacji badanego enzymu rok po pożarze. Metoda grupowania Warda pozwoliła na określenie podobieństw między badanymi stanowiskami w dwóch latach badań (2012 i 2013 rok) na podstawie wybranych parametrów glebowych. Na podstawie metody PCA stwierdzono negatywny wpływ pożaru.

Słowa kluczowe: katalaza, metale ciężkie, pożar lasu 